\title{
Faktor dan Dampak Perkawinan dalam Masa Iddah (Studi Kasus di Kecamatan Trimurjo Lampung Tengah)
}

\author{
Habib Ismail $^{1 \mathrm{a}}$ dan Nur Alfi Khotamin ${ }^{1 \mathrm{~b}}$ \\ ${ }^{1}$ Institut Agama Islam Ma'arif NU Metro Lampung \\ e-mail: ${ }^{a}$ habibismail65@gmail.com, \\ buralfimimin17@gmail.com
}

\begin{abstract}
This research was written to explain about marriage in the period of iddah perspective of Islamic Law and marriage law. The complexity of marriage problems is shown by various problems that arise from time to time and if viewed from the sociological side influenced by social changes as the times that cause changes Way of thinking then influences the way of action that changes the way of life in general and the Muslim in particular. One of the problems arising from such social change is marriage done in the iddah period. Which results in both the indvidual and social impact of society.

This type of research is a field of research that is descriptive qualitative. By using qualitative data collection techniques. This analysis is expected to produce a more objective and systematic description of the factors and impacts of marriage in the Islamic legal perspective and marriage law (case study in Trimurjo sub-district, Central Lampung district).

From the above research, the researcher got the conclusion that the factors and the impact of marriage done in the iddah period are internal factors (educational, economic and biological factors) and external factors (the lack of control over religious figures and the public) while the impact of the marriage is the impact of the individual And social.
\end{abstract}

Keywords: Marriage, Iddah Period, Islamic Law, Marriage Law. 


\section{Abstrak}

Penelitian ini ditulis untuk menjelaskan mengenai pernikahan dalam masa iddah perspektif Hukum Islam dan Undang-undang perkawinan.kompleksitas permasalahan perkawinan ini ditunjukkan oleh berbagai macam problematika yang muncul dari zaman ke zaman dan jika dilihat dari sisi sosiologis dipengaruhi oleh perubahan sosial seiring perkembangan zaman yang menyebabkan perubahan way of thinking (cara berfikir) manusia kemudian mempengaruhi way of action (cara bertindak) yang mengubah way of life (cara hidup) manusia secara umum dan muslim secara khusus. Salah satu problematika yang muncul akibat perubahan sosial tersebut adalah perkawinan yang dilakukan dalam masa iddah. Yang berakibat dampak baik dari sisi indvidual maupun sosial masyarakat.

Jenis penelitian ini adalah field research yang bersifat diskriptif kualitatif. Dengan menggunakan tehnik pengumpulan data secara analisis kualitatif. Dengan analisis ini diharapkan dapat menghasilkan deskripsi yang lebih objektif dan sistematis tentang faktor dan dampak perkawinan dalam masa iddah perspektif hukum Islam dan Undang-undang perkawinan (studi kasus di Kecamatan Trimurjo, Kabupaten Lampung Tengah).

Dari penelitian diatas peneliti mendapat kesimpulan bahwasanya faktor-faktor dan dampak dari perkawinan yang dilakukan dalam masa iddah adalah faktor internal (faktor pendidikan, ekonomi dan biologis) dan faktor eksternal (lemahnya tingakat kontrol tokoh Agama dan Publik. Sedangkan dampak dari pernikahan tersebut adalah dampak individual dan sosial.

Kata Kunci: Perkawinan, Masa Iddah, Hukum Islam, Undang-undang Perkawinan.

\section{A. Pendahuluan}

\section{Latar Belakang}

Pernikahan merupakan ikatan batin seorang pria dan wanita sebagai suami istri dengan membentuk keluarga yang bahagia dan kekal berdasarkan Tuhan Yang Maha Esa. 
Dalam Islam pernikahan masuk dalam kategori ibadah. ${ }^{1}$ Pernikahan juga merupakan salah satu sunnatullah atas seluruh ciptaan-Nya, tidak terkecuali manusia, hewan dan tumbuh-tumbuhan. ${ }^{2}$ Sesuai dengan firman Allah Swt. dalam surat Ar-Rum [30]: 21 bahwa,

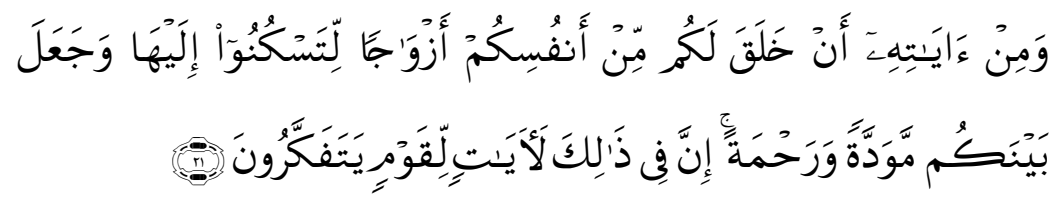

Artinya "Dan di antara tanda-tanda kekuasaan-Nya ialah dia menciptakan untukmu isteri-isteri dari jenismu sendiri, supaya kamu cenderung dan merasa tenteram kepadanya, dan dijadikan-Nya diantaramu rasa kasih dan sayang. Sesungguhnya pada yang demikian itu benar-benar terdapat tanda-tanda bagi kaum yang berfikir. ${ }^{3}$

Dalam pandangan Islam perkawinan itu bukanlah hanya urusan perdata semata, bukan pula sekedar urusan keluarga dan masalah budaya, tetapi masalah dan peristiwa agama, oleh karena perkawinan itu dilakukan untuk memenuhi sunnah Allah dan sunnah Nabi ${ }^{4}$. Di samping itu, perkawinan juga bukan untuk mendapatkan ketenangan hidup sesaat, tetapi untuk selama hidup. ${ }^{5}$ Oleh karena itu perkawinan menjadi suatu hal yang memiliki urgensi yang inherent di dalam kehidupan manusia, di mana mencakup seluruh bidang kehidupan baik sosial, politik, ekonomi menjadi memiliki keterkaitan dan mampu memicu terjadinya konflik sehingga menumbukhan permasalah yang kompleks.

${ }^{1}$ Zainuddin Ali, Hukum Perdata Islam di Indonesia, Jakarta: Sinar Grafika, 2009, h. 7.

2 Abdul Azziz Muhammad Azzam dan Abdul Wahab Sayyed Hawwas, Fiqh Munakahat: Khitbah, Nikah, dan Talak, Alih bahasa Abdul Majid Khon, Jakarta: Amzah, 2009, h. 37.

${ }^{3}$ Dewan Penterjemah, Al Qur"an dan Terjemahannya, Madinah: Mujamma"e Al Malik Fahd Li Thiba"eat Al Mush-haf, 1971, h. 644.

4 Arso Sosroatmodjo, Wasit Aulawi, Hukum Perkawinan di Indonesia, Jakarta: Bulan Bintang, 1975, h. 33.

${ }^{5}$ Amir Syarifuddin, Hukum Perkawinan Islam di Indonesia antara Fiqh Munakahat dan Undang-undang Perkawinan, Jakarta: Kencana Prenada Media Group, 2009, h. 48. 
Kompleksitas permasalahan perkawinan ini ditunjukkan oleh berbagai macam problematika yang muncul dari zaman ke zaman dan jika dilihat dari sisi sosiologis dipengaruhi oleh perubahan sosial seiring perkembangan zaman yang menyebabkan perubahan way of thingking (cara berfikir) manusia kemudian mempengaruhi way of action (cara bertindak) yang mengubah way of life (cara hidup) manusia secara umum dan muslim secara khusus. Hal tersebut tidak lepas dari perubahan sosial yang dipengaruhi oleh berbagai bidang kehidupan.

Problematika perkawinan tersebut yang muncul antara lain pernikahan dini, pernikahan beda agama, pernikahan campuran (beda kewarganegaraan), pernikahan sirri, yang berakiblat pada fakta perceraian. Akibat dari perceraian tersebut muncullah beberapa hukum bagi seorang perempuan diantaranya adalah 'iddah atau masa tunggu.

Selanjutnya ada kewajiban masa 'iddah bagi wanita yang mengalami perceraian. Telah ditegaskan dalam AlQur'an bahwa dalam keadaan apapun yang dialami pihak wanita, ia wajib melaksanakan "iddah. Allah Swt. berfirman,

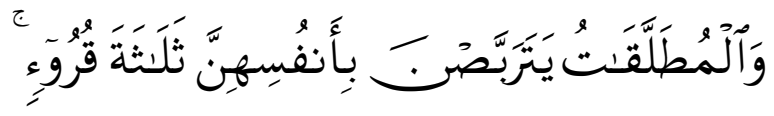

Artinya "Wanita-wanita yang ditalak hendaklah menahan diri (menunggu) tiga kali quru'.

Dalam Al-Qur'an, tidak dibenarkan bagi perempuanperempuan yang sedang menjalani masa iddah untuk bersuami lagi. ${ }^{7}$ Ketentuan mengenai keharaman nikah dalam masa iddah ini juga disebutkan dalam Kompilasi Hukum Islam (selanjutnya di sebut KHI) Indonesia BAB VI Pasal 40 huruf $b$ tentang Larangan Kawin, bahwa dilarang melangsungkan pernikahan apabila seorang wanita masih berada dalam masa 'iddah dengan pria lain. Firman Allah Swt.:

${ }^{6}$ Dewan Penterjemah, Al Qur"an, 1971, h. 55.

7 Sayyid Sabiq, Fiqih Sunnah 3, Alih bahasa M. Ali Nursyidi dan Hunainah M. Thahir Makmun, Jakarta: PT. Pena Pundi Aksara, 2009, h. 117. 


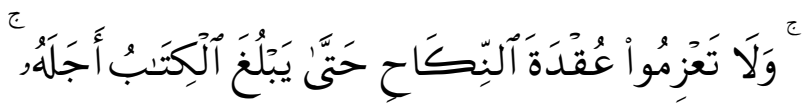

Artinya "dan janganlah kamu ber'azam (bertetap hati) untuk beraqad nikah, sebelum habis 'iddahnya. ${ }^{8}$

\section{Rumusan Masalah}

Berdasarkan latar belakang tersebut, penulis merasa tertarik untuk menelusuri lebih dalam mengenai faktor dan dampak dalam pernikahan istri (janda) yang belum habis masa 'iddah-nya. Selanjutnya pembahasan akan diperkaya dengan pandangan yang berlandaskan Hukum Islam dan Undang-undang Perkawinan. Menanggapi perihal di atas, maka penulis akan merumuskan permasalahan menjadi dua. Yang pertama Apakah faktor dan dampak perkawinan yang dilakukan dalam masa 'iddah?

\section{B. Kerangka Teori}

\section{Pengertian Iddah}

'Iddah diambil dari kata al-add ${ }^{9}$ dan al-ihshâ', yaitu sesuatu yang dihitung ${ }^{10}$ oleh perempuan. 'Iddah adalah sebutan dari masa bagi perempuan untuk menunggu dan mencegahnya untuk menikah setelah suaminya wafat atau setelah berpisah dengannya. Kemudian karena sebab-sebab itu, maka masa 'iddah-nya terhitung. ${ }^{11}$ Firman Allah Swt.,

\footnotetext{
${ }^{8}$ Dewan Penterjemah, Al Qur"an, 1971, h. 59.

${ }^{9}$ Syekh Sayyid Sabiq, Fiqh Sunnah Juz 2, (Libanon: Bairut, 2007), h. 622 .

${ }^{10}$ Umi Hasunah, Susanto, Iddah Perempuan Hamil karena Zina dalam Kompilasi Hukum Islam Pasal 53, Jurnal Hukum Keluarga Islam Volume 1, Nomor 1, April 2016, h. 101. Lihat juga Indar, Iddah Dalam Keadilan Gender, Jurnal Studi Gender \& Anak Vol.5 No.1 Jan-Jun 2010 pp.103-127, h. 6. Lihat juga Siti Zulaikha, 'Iddah Dan Tantangan Modernitas, ISTINBATH Jurnal Hukum Vol. 7 Nomor 1 MEI 2010, h. 85.

11 Ali Yusuf As-Subki, Fiqh Keluarga: Pedoman Berkeluarga dalam Islam, Jakarta: Amzah, 2010, h. 348.
} 


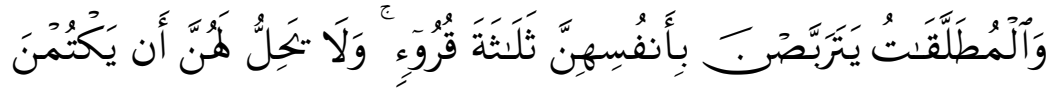

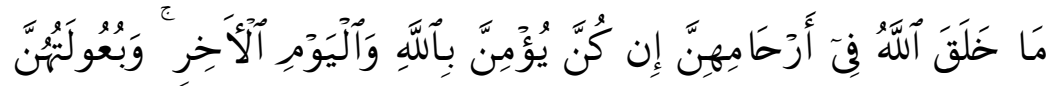

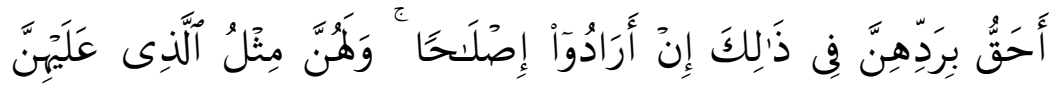

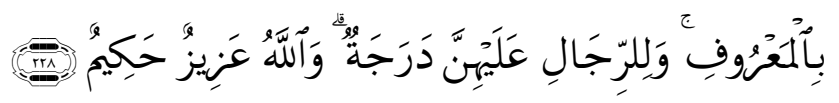

Artinya “ Wanita-wanita yang ditalak handaklah menahan diri (menunggu) tiga kali quru'. tidak boleh mereka menyembunyikan apa yang diciptakan Allah dalam rahimnya, jika mereka beriman kepada Allah dan hari akhirat. dan suami-suaminya berhak merujukinya dalam masa menanti itu, jika mereka (para suami) menghendaki ishlah. dan para wanita mempunyai hak yang seimbang dengan kewajibannya menurut cara yang ma'ruf. akan tetapi para suami, mempunyai satu tingkatan kelebihan daripada isterinya. dan Allah Maha Perkasa lagi Maha Bijaksana.(Q.S. al-Baqarah: 228).

Dari ayat Al-Qur'an di atas telah jelas bahwa 'iddah hukumnya wajib bagi seorang wanita yang baru saja dinyatakan sah berpisah (cerai) dari suaminya. Dalam firmanNya Allah Swt. juga menentukan tentang adab suami ketika ingin menalak istrinya yang berkaitan dengan masa ' $i d d a h{ }^{12}$ Firman Allah Swt.:

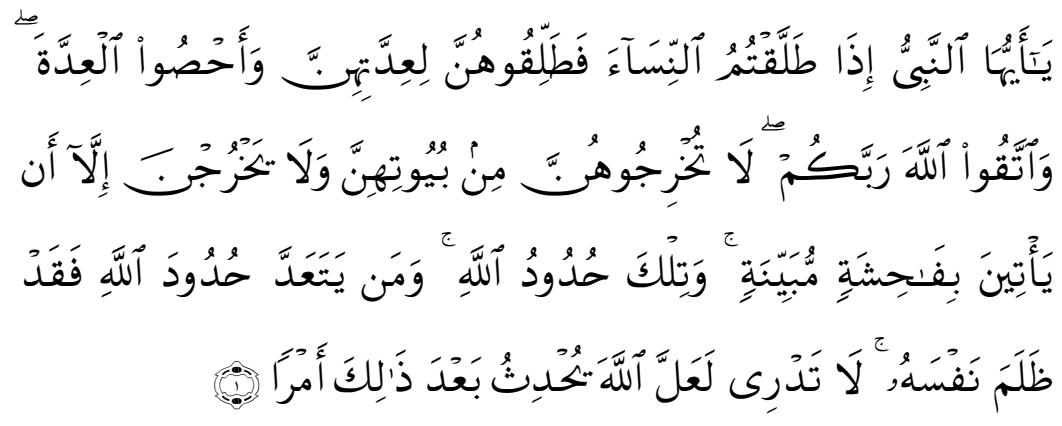

Artinya "Hai nabi, apabila kamu menceraikan Isteriisterimu Maka hendaklah kamu ceraikan mereka pada waktu

${ }^{12}$ Ibnu Hajar Al Asqalani, Fathul Barri 26: Shahih Bukhari, Alih bahasa Amiruddin, Jakarta: Pustaka Azzam, 2008, h. 2. 
mereka dapat (menghadapi) iddahnya (yang wajar) dan hitunglah waktu iddah itu serta bertakwalah kepada Allah Tuhanmu. janganlah kamu keluarkan mereka dari rumah mereka dan janganlah mereka (diizinkan) ke luar kecuali mereka mengerjakan perbuatan keji yang terang. Itulah hukum-hukum Allah, Maka Sesungguhnya dia Telah berbuat zalim terhadap dirinya sendiri. kamu tidak mengetahui barangkali Allah mengadakan sesudah itu sesuatu hal yang baru.(Q.S. Ath Thalaq: 1)

Hal ini juga dijelaskan kembali oleh Nabi Muhammad Saw. ketika memerintahkan Fathimah binti Qais sebagai berikut:

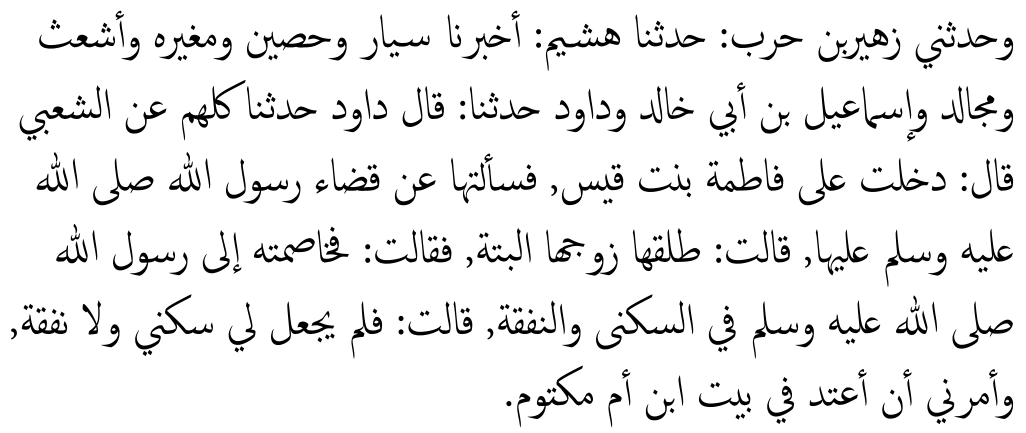

Artinya: Zuhair bin Harn menyampaikan kepadaku dari Husyaim dari Sayyar, Hushain, Mughirah, Asy"ats, Mujalid, Ismail bin Abu Khalid, dan Dawud yang mengabarkan Dawud menggunakan lafaz haddatsanâ seluruhnya dari asy- Sya"bi mengatakan, "Aku masuk menemui Fathimah binti Qais: Aku bertanya tentang keputusan Rasulullah Saw. atas dia. Dia mengatakan bahwa suaminya menalaknya dengan talak ba"in. Dia menuturkan, „Aku mengadukannya kepada Rasulullah Saw. tentang hak tempat tinggal dan nafkah. Namun beliau tidak menetapkan hak tempat tinggal dan nafkah. Namun, beliau memerintahkanku untuk menjalani 'iddah di rumah Ibnu Ummu Maktum".,"13

13 An-Naisaburi dan Muslim bin al-Hajjaj al-Qusyairi, Ensiklopedia Hadits 3: Shahih Muslim 1, Alih bahasa Ferdinand Hasmand, dkk, Jakarta: Almahira, 2012, h. 724. 
Az-Zamakhsyari berkata bahwa ayat ke 228 Surah AlBaqarah ini berbentuk makna perintah. Berasal dari perkataan "Hendaklah wanita-wanita itu menunggu". Maka mengeluarkan perintah dalam bentuk kalimat berita bermakna penguat perintah dan memberi isyarat sesuatu yang wajib diterima dan agar segera dipatuhi. Artinya, 'iddah diwajibkan, dan seluruh fuqaha sepakat dengan hal tersebut. ${ }^{14}$

Quru'diterangkan dalam Surah Al-Baqarah ayat 228 dan mengandung dua pengertian yang berlawanan, yaitu masa haid dan masa suci. Ulama berbeda pendapat tentang ini. Imam Malik, Imam Syafieci, dan Imam Ahmad dalam salah satu pendapatnya, mengatakan bahwa quru'artinya suci. Sedangkan Imam Abu Hanifah dan Imam Ahmad (dalam riwayat yang lain) berpendapat bahwa quru' artinya haid. ${ }^{15}$

ثلثة قروء Adapun beberapa penafsiran lain dari kalimat (tiga kali quru') dalam ayat sebelumnya, adalah oleh Imam Jalaluddin dalam kitab Jalalain, memaparkan bahwa kata "quru" adalah jamak dari "qar-un" dengan mem-fatah-kan qaf, dan atasnya ada yang mengatakan suci dan ada pula haid. ${ }^{16}$ Kemudian Ibnu Katsir dalam kitab yang berjudul Tafsir Ibnu Katsir bahwa quru'yang dimaksud adalah waktu tertentu untuk tiba dan hilangnya sesuatu. Karena itu haid dan suci, keduanya dinamakan quru'. ${ }^{17}$

Wahbah Zuhaili secara jelas memaparkan kata quru' memiliki arti haid, dengan bersandar pada beberapa dalil, AlQur'an maupun Hadis. Pendapat ini lebih utama dari pendapat yang lain. Karena 'iddah dijalani untuk membersihkan rahim, maka dilakukan dengan haid. Dengan begitu tujuan 'iddah tercapai dengan pengertian quru' yang berarti haid. Dan kebersihan rahim hanya dapat diketahui dengan datangnya haid. Jika seorang wanita mengalami haid

14 Abdul Aziz Muhammad Azzam dan Abdul Wahhab Sayyed Hawwas, Fiqh Munakahat: Khitbah, Nikah dan Talak, h. 319.

${ }^{15}$ Ahsin W. Alhafidz, Kamus Fiqh, Jakarta: Amzah, 2013, h. 186.

${ }^{16}$ Imam Jalaluddin Al-Mahalli dan Imam Jalaluddin Al- Suyuthi, Tafsir Jalalain 1: Berikut Asbaabun Nuzuul Ayat, Alih bahasa Bahrun Abu Bakar, Bandung: Sinar Baru Algesindo, 1996, h. 125.

${ }^{17}$ Salim Bahreisy dan Said Bahreisy (pengh. dan pent.), Terjemah Singkat Tafsir Ibnu Katsir Jilid 1, Surabaya: PT. Bina Ilmu, 2006, h. 438. 
maka dapat dipastikan bahwa dia tidak hamil. Namun ketika terus suci maka bisa dipastikan ia mengalami kehamilan. 'Quru yang diartikan sebagian orang sebagai haid disebabkan terhimpunnya darah di dalam rahim.

Dari penjelasan di atas diketahui bahwa pengertian quru' yang paling kuat adalah suci. Ini merujuk pada pendapat yang paling masyhur, yaitu pendapat Imam Syafi'i. Selain Imam Syafi'i, yang berpendapat quru' adalah suci yaitu pendapat dari Aisyah ra, Ibnu Umar, Zaid bin Tsabit, Az-Zuhri, dan Aban bin Utsman. Dari pendapat Imam Syafi'i, dapat diketahui bahwa haid menjadi pemisah antara suci yang satu dengan suci yang lainnya. Karena jatuhnya talak yang disyariatkan adalah ketika perempuan sedang suci, maka quru' adalah perubahan dari masa suci ke masa haid. Hal ini bertujuan untuk mengetahui kosongnya rahim yang menjadi hikmah 'iddah sendiri.

\section{Perhitungan Iddah}

Masa 'iddah dimulai setelah terjadinya tiga perkara: ${ }^{18}$ talak, fasakh atau kematian. Adapun perhitungan 'iddah bagi seorang perempuan yang telah berpisah dari suaminya:

1) Iddah wanita yang belum disetubuhi, maka tidak ada iddah baginya. ${ }^{19}$ Firman Allah Swt.: Surah Al-Azhab [33]: 49.
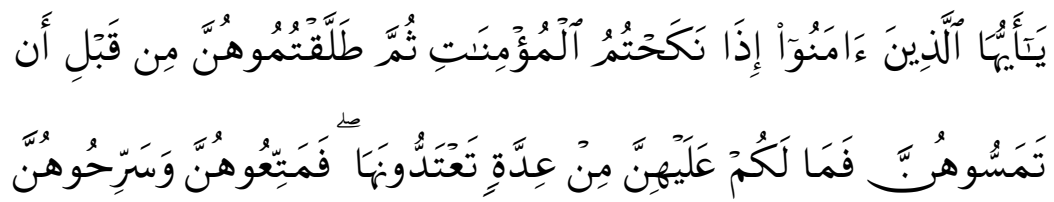

$$
\text { سَرَاحَا جَمِيًَا }
$$

Artinya: "Hai orang-orang yang beriman, apabila kamu menikahi perempuan- perempuan yang beriman, kemudian kamu ceraikan mereka sebelum kamu mencampurinya Maka sekali-sekali tidak wajib atas mereka

${ }^{18}$ Imam Ghazali Said dan Achmad Zaidun, Terjemah Bidayatul Mujtahid Analisis Fiqih Para Mujtahid, (Jakarta: Pustaka Amani, 2017), h. 617.

${ }^{19}$ Sayyid Sabiq, Fiqih Sunnah 3, h. 118. 
'iddah bagimu yang kamu minta menyempurnakannya. Maka berilah mereka mut'ah dan lepaskanlah mereka itu dengan cara yang sebaik- baiknya."

2) 'Iddah wanita yang haid adalah tiga kali 'quru. Firman Allah Swt.: Surah Al Baqarah [2]: 228.

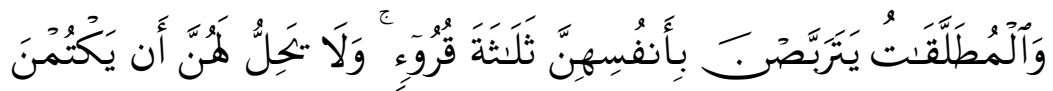

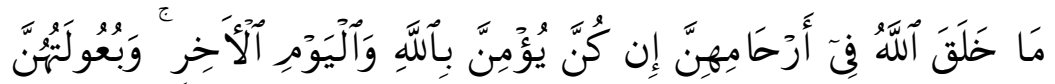

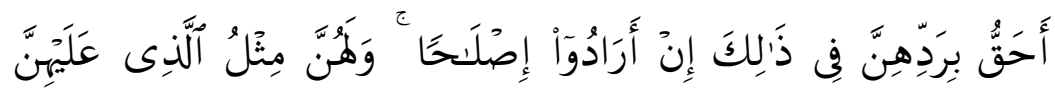

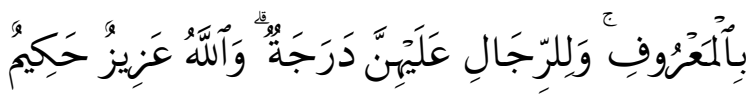

Artinya: "Wanita-wanita yang ditalak handaklah menahan diri (menunggu) tiga kali quru' tidak boleh mereka Menyembunyikan apa yang diciptakan Allah dalam rahimnya, jika mereka beriman kepada Allah dan hari akhirat. dan suami-suaminya berhak merujukinya dalam masa menanti itu, jika mereka (para suami) menghendaki ishlah. dan Para wanita mempunyai hak yang seimbang dengan kewajibannya menurut cara yang ma'ruf. akan tetapi Para suami, mempunyai satu tingkatan kelebihan daripada isterinya. dan Allah Maha Perkasa lagi Maha Bijaksana.

3) Iddah wanita yang tidak haid adalah tiga bulan. Firman Allah Swt.: Surah Ath Thalaq [65]: 4.
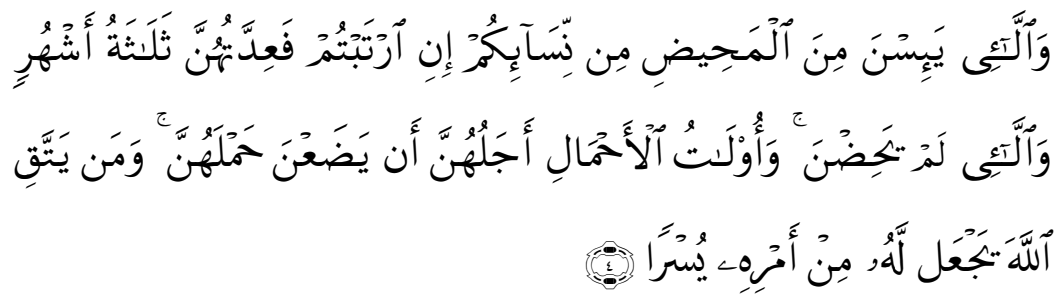

Artinya: "Dan perempuan-perempuan yang tidak haid lagi (monopause) di antara perempuan-perempuanmu jika kamu ragu-ragu (tentang masa iddahnya), Maka masa iddah mereka adalah tiga bulan; dan begitu (pula) perempuanperempuan yang tidak haid. dan perempuan-perempuan yang 
hamil, waktu iddah mereka itu ialah sampai mereka melahirkan kandungannya. dan barang -siapa yang bertakwa kepada Allah, niscaya Allah menjadikan baginya kemudahan dalam urusannya."

4) Iddah wanita yang masih haid tapi tidak terlihat haid adalah selama setahun. Syafie i berkata, "Hal ini yang diputuskan oleh Umar bin Khattab r.a. kepada Muhajirin dan Anshar. Tidak ada satupun dari mereka yang membantah keputusan Umar bin Khattab r.a. ini."

5) 'Iddah wanita dalam keadaan hamil adalah hingga melahirkan. ${ }^{20}$ Firman Allah Swt.: Surah Ath Thalaq [65]: 4 .

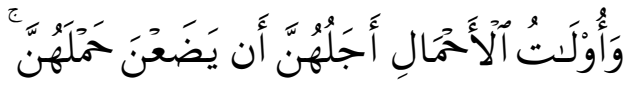

Artinya“......dan perempuan-perempuan yang hamil, waktu iddah mereka itu ialah sampai mereka melahirkan kandungannya.

6) 'Iddah wanita yang ditinggal mati suaminya adalah selama 4 bulan 10 hari. Firman Allah Swt.: Surah Al Baqarah [2]: 234.

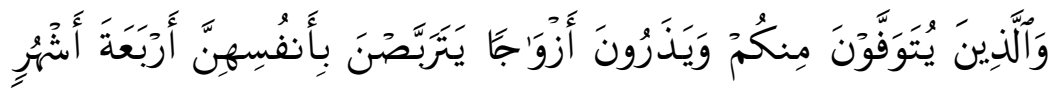

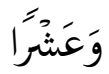

Artinya: "Orang-orang yang meninggal dunia di antaramu dengan meninggalkan isteri-isteri (hendaklah Para

${ }^{20}$ Syarifudin Anwar dan Misbah Musthafa, Terjemah Kifayatul Ahyar Kelengkapan Orang Saleh, (Surabaya: Bina Iman). h. 258. Lihat juga, Ibnu Mas'ud dan Zainal Abidin S, Fiqih Madzhab Imam Syafi'I, (Bandung: Pustaka Setia, 2007), h. 374. Lihat juga Indar, Iddah Dalam Keadilan Gender, Jurnal Studi Gender \& Anak Vol.5 No.1 Jan-Jun 2010 pp.103-127, h. 8 . 
isteri itu) menangguhkan dirinya (ber'iddah) empat bulan sepuluh hari. ${ }^{21}$

7) 'Iddah wanita istihadah ${ }^{22}$ adalah sama dengan kebiasaan haidnya. Namun apabila tergolong wanita yang menopause maka iddah-nya akan berakhir setelah melewati masa tiga bulan.

Adapun perhitungan masa 'iddah yang diatur dalam Pasal 153 Ayat 2 Kompilasi Hukum Islam bahwa masa 'iddah bagi wanita yang ditinggal mati adalah 130 hari. Masa 'iddah perceraian bagi wanita yang masih haid adalah tiga kali suci atau sekurang-kurangnya 90 hari, dan masa 'iddah bagi wanita menopause adalah 3 bulan atau 90 hari. Masa ,iddah bagi janda yang berada dalam keadaan hamil adalah sampai ia melahirkan. Serta masa 'iddah bagi wanita yang ditinggal mati sedang ia dalam kondisi hamil, maka 'iddahnya hanya sampai ia melahirkan. ${ }^{23}$

Penulis memahami bahwa dalam Hukum Pernikahan di Indonesia, memiliki ikhtiyati yang tinggi terhadap 'iddah. Diketahui bahwa masa 'iddah bagi wanita ba'da dukhul adalah tiga kali quru'. Sedangkan siklus haid dan kesucian wanita itu bersifat subjektif, sehingga tercapainya kesempurnaan 'iddah juga berbeda, ada yang kurang dari tiga bulan dan ada yang lebih. Maka Hukum Perkawinan di Indonesia yang tertuang dalam Kompilasi Hukum Islam (KHI) dan Undang-Undang No. 1 Tahun 1974 tentang Perkawinan mencoba untuk berhati-hati dalam memberikan ketentuan masa 'iddah. Dan sejalan dengan hukum administratif di Indonesia tentang pernikahan dan talak, bahwa wanita janda (talak raj'i) boleh menikah kembali saat mencukupi masa 'iddah tiga kali qurue yaitu 90 hari.

21 St. Kuraedah, Hadis Tentang Iddah Wanita Hamil Yang Ditinggal Mati Oleh Suaminya, Jurnal Al-‘Adl, Vol. 6 No. 1 Januari 2013, h. 144.

22 Istihadah atau mustahadhah adalah perempuan yang terusmenerus mengeluarkan arah dari kemaluannya karena penyakit tertentu, keluarnya darah itu tidak pada masa-masa haid dan nifas.

${ }^{23}$ Zainuddin Ali, Hukum Perdata Islam di Indonesia, h. 88. 


\section{Hak dan Kewajiban Perempuan dalam masa Iddah}

Allah mewajibkan 'iddah bagi wanita muslimah demi melindungi kehormatan keluarga serta menjaga dari perpecahan dan pencampuran nasab. Hal ini merupakan ibadah karena merupakan wujud pelaksanaan perintah Allah Swt. terhadap muslimah-muslimah dimuka bumi. ${ }^{24}$ Islam sangat hati-hati menjaga martabat perkawinan, serta mengajarkan untuk menghormati ikatan perkawinan. Sebagaimana ikatan perkawinan tidak terlaksana kecuali adanya wali dan saksi, maka ikatannya juga tidak terlepas kecuali dengan menunggu dalam jangka waktu yang lama. Adapun hikmah dari menjalankan 'iddah bagi seorang perempuan yang telah berpisah dari suaminya:

1) Mengetahui kebebasan rahim dari pencampuran nasab. ${ }^{25}$

2) Memberi kesempatan dan peluang kepada suami dan istri yang telah bercerai untuk rujuk kembali memperbaiki hubungan (dalam talak raj'i). Merupakan bentuk kasih sayang Allah Swt. kepada hamba-Nya dengan menyadari bahwa selama masa menunggu itu orang akan sadar betapa nikmat hidup berkeluarga dan betapa meruginya hidup sendirian.

3) Menghormati almarhum suami yang meninggal, bila 'iddah-nya ditinggal mati oleh suami. ${ }^{26}$

4) Menjunjung tinggi pernikahan. 'Iddah dapat dimanfaatkan untuk menghimpun orang-orang arif lalu mengompromikan permasalahan dan memberikan tempo untuk berpikir panjang. Jika tidak demikian, pernikahan tidak ubahnya seperti permainan anak-anak disusun dengan cepat dan dirusak dengan cepat pula. ${ }^{27}$

${ }^{24}$ Muhammad Ali Ash-Shabuni, Terjemahan Tafsir Ayat Ahkam Ash-Shabuni, Alih bahasa Mu'ammal Hamidy dan Imron A. Manan, Surabaya: PT Bina Ilmu, 2008, h. 261.

25 Abdul Aziz Muhammad Azzam dan Abdul Wahhab Sayyed Hawwas, Fiqh Munakahat: Khitbah, Nikah dan Talak, h. 320.

${ }^{26}$ Tim Almanar, Fikih Nikah, Bandung: Syamil, 2003, h. 147.

${ }^{27}$ Ahsin W. Alhafidz, Kamus Fiqh, h. 81. 


\section{Larangan dalam Masa Iddah}

Sayyid Sabiq mengatakan bahwa istri yang sedang menjalani masa 'iddah berkewajiban untuk menetap di rumah dimana dia dahulu tinggal bersama sang suami sampai selesai masa 'iddahnya dan tidak diperbolehkan baginya keluar dari rumah tersebut. Sedangkan si suami juga tidak boleh mengeluarkan ia dari rumahnya, sebagaimana disebutkan dalam firman Allah pada surat al-Thalak ayat pertama. Seandanya terjadi perceraian diantara mereka berdua, sedang istrinya tidak berada di rumah dimana mereka berdua menjalani kehidupan rumah tangga, maka si istri wajib kembali kepada suaminya untuk sekedar suaminya mengetahuinya dimana ia berada. ${ }^{28}$

Ulama fiqh mengemukakan bahwa ada beberapa larangan bagi perempuan yang sedang menjalani masa 'iddahnya antara lain:

1) Tidak boleh dipinang oleh laki-laki lain baik secara terang-terangan maupun melalui sindiran, akan tetapi untuk wanita yang menjalani iddah kematian suami pinangan dapat dilakukan secara sindiran.

2) Dilarang keluar rumah. Jumhur ulama fiqh selain Mazhab Hanbali sepakat menyatakan bahwa perempuan yang menjalani 'iddah dilarang keluar rumah apabila tidak ada keperluan mendesak, akan tetapi Ulama' Mazhab Hanbali berpendapat bahwa wanita yang dicerai baik cerai hidup maupun cerai mati boleh keluar rumah. ${ }^{29}$

3) Al-Ahdad artinya membatasi diri. Yang dimaksud dengan membatasi diri disini ialah larangan memakai perhiasan yang bermewah-mewah dan wangi-wangian. ${ }^{30}$

28 Imam Syafi'i, Mukhtasar Kitab Al-Umm Fi Al-Fiqh, diterjemahkan Muh. Yasir Muthalib Cet 3, Jakarta: Pustaka Azzam, 2007, h. 513.

${ }^{29}$ Sayyid Sabiq, Terjemah Fiqih Sunnah jilid 3, (Jakarta: Pena Pundi Aksara, 2007), h. 234.

${ }^{30}$ Ibnu Mas'ud, Zainal Abidin S, Fiqih Madzhab Syafi'i Buku 2, (Bandung: Pustaka Setia, 2007), h. 378. 


\section{Hak-hak Istri dalam masa 'Iddah}

Fuqaha sependapat bahwa istri yang sedang ber'iddah bak talak raj' $i$ maupun hamil memperoleh nafkah dan tempat tinggal $^{31}$, berdasarkan firman Allah:
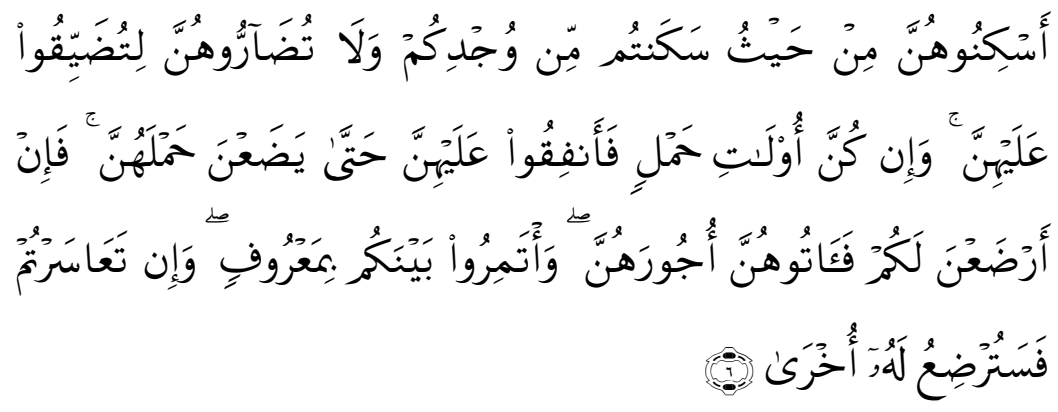

Artinya "Tempatkanlah mereka (para isteri) di mana kamu bertempat tinggal menurut kemampuanmu dan janganlah kamu menyusahkan mereka untuk menyempitkan (hati) mereka. dan jika mereka (isteri-isteri yang sudah ditalaq) itu sedang hamil, Maka berikanlah kepada mereka nafkahnya hingga mereka bersalin, Kemudian jika mereka menyusukan (anak-anak)mu untukmu Maka berikanlah kepada mereka upahnya, dan musyawarahkanlah di antara kamu (segala sesuatu) dengan baik; dan jika kamu menemui kesulitan Maka perempuan lain boleh menyusukan (anak itu) untuknya."'(QS. Ath-Thalaq: 6)

Kemudian fuqaha berselisih pendapat mengenai tempat tinggal dan nafkah bagi istri yang ditalak. Diantara pendapat tersebut adalah:

1) Wanita yang taat dalam 'iddah raj'i berhak menerima tempat tinggal, pakaian, dan segala keperluan hidupnya, kecuali istri durhaka yang tidak berhak menerima apa-apa. ${ }^{32}$

${ }^{31}$ Ibnu Rusyd, Bidayatul Mujtahid Analisis Fiqih Para Mujtahid, Alih Bahasa Imam Ghazali Said dan Achmad Zaidun, (Jakarta: Pustaka Amani, 2007), h. 614.

${ }^{32}$ Sulaiman Rasyid, Fiqh Islam, Bandung: Sinar Baru Algensindo, 1994, h. 416. 
2) Wanita yang berada dalam 'iddah ba'in, jika mengandung maka ia juga berhak atas tempat tinggal, makanan dan pakaian.

3) Wanita yang berada dalam 'iddah ba'in yang tidak hamil, hanya berhak mendapatkan tempat tinggal, tidak untuk yang lain.

\section{Hikmah Iddah}

Masalah iddah yang merupakan suatu syari'at yang telah ada sejak zaman dahulu yang mana mereka tidak pernah meninggalkan kebiasaan ini dan tatkala Islam datang kebiasaan itu diakui dan dijalankan terus karena banyak terdapat kebaikan dan faedah di dalamnya. ${ }^{33}$ Para Ulama telah mencoba menganalisa hikmah disyariatkannya iddah dapat disebutkan sebagai berikut: pertama, ialah sebagai pembersih rahim ${ }^{34}$, yang kedua, adalah sebagai kesempatan untuk berfikir bagi kedua belah pihak agar dapat mengintropeksi diri masing-masing guna mengambil langkah-langkah yang lebih baik $^{35}$. Yang ketiga adalah kesempatan untuk berduka cita dan yang terakhir keempat adalah kesempatan untuk rujuk. Apabila seorang istri dicerai karena thalak yang mana mantan suami tersebut masih berhak untuk merujuk istrinya kembali. Dan apabila sang istri tidak mau maka, ia harus melepas mantan istrinya secara baik-baik dan jangan menghalang-halangi mantan istrinya itu untuk menikah dengan laki-laki lain. ${ }^{36}$

\section{Gambaran Umum Lokasi dan Tempat Penelitian}

Nama Trimurjo diambil dari bahasa Jawa yang berarti Tri: tiga dan Rejo: kemakmuran. Hal ini didasarkan pada adanya saluran irigasi bercabang tiga di Trimurjo yang menyebarkan air ke wilayah Lampung Tengah dan

\footnotetext{
h. 140 .

${ }^{34}$ Kamal Muhtar, Asas Hukum Perkawinan, cet. II, Jakarta: Bulan Bintang, 1987, h. 230.

Soemiyati, Hukum Perkawinan dan Undang-undang Perkawinan, cet. I, Yogyakarta: Liberty, 1982.

${ }^{36}$ Ibid, h. 230.
}

${ }^{33}$ Sayyid Sabiq, Fiqh as-Sunnah, Beirut: Dar al-Kutub al 'Ilmiyah, 
sekitarnya. Saluran irigasi menandakan kemakmuran karena padi dan pertanian dapat tumbuh subur dengan air yang tercukupi.

Kecamatan Trimurjo adalah tempat pertama dari tujuan transmigrasi pada zaman Belanda. Oleh karena itu istilah "bedeng" masih populer di kecamatan tersebut. Bedeng berarti kompleks lokasi rombongan para transmigran dari Jawa dan dibagi-bagi dalam bedeng-bedeng. Misal kelurahan Adipuro terdiri dari Bedeng 2 (Dusun Adirejo, Dusun Tegalrejo) dan Bedeng 3 (Dusun Widoro Kandang). Bedeng 4, 5, 10 (kelurahan Trimurjo), bedeng 6, 7 (kampung Liman Benawi), bedeng 7 dan 8 (Depokrejo), bedeng 11 (Simbarwaringin), bedeng 12 (Tempuran), bedeng 13 (Purwodadi), bedeng 17, 18, 19 (Pujodadi), bedeng 20 (Purwodadi), dll.

Untuk faktor sejarah pembentukan Metro pada zaman kolonial, untuk Trimurjo memang tidak bisa dipisahkan. Metro adalah "bedeng yang menjadi kota", yang awal mula koloni berada di Bedeng 1 (Trimurjo) sampai Bedeng 67 di Sekampung. Sejarah kelahiran Kota Metro bermula dengan dibangunnya sebuah induk desa baru yang diberi nama Trimurjo. Dibangunnya desa ini dimaksudkan untuk menampung sebagian dari kolonis yang didatangkan oleh perintah Hindia belanda pada tahun 1934 dan 1935, serta untuk menampung kolonis-kolonis yang akan didatangkan berikutnya.

Berikut ini adalah luas wilayah menurut jenis lahan di Kecamatan Trimurjo (hektar) tahun 2014.

Tabel 1

Luas wilayah menurut jenis lahan di Kecamatan Trimurjo (hektar) tahun 2016.

\begin{tabular}{|c|l|l|c|c|}
\hline No. & $\begin{array}{c}\text { Desa/ } \\
\text { Kampung }\end{array}$ & $\begin{array}{c}\text { Lahan } \\
\text { Sawah }\end{array}$ & $\begin{array}{c}\text { Lahan Bukan } \\
\text { Sawah }\end{array}$ & Jumlah \\
\hline \hline 1 & Adipuro & 325.70 & 175.10 & 500.80 \\
\hline 2 & Liman Benawi & 325.00 & 98.17 & 423.17 \\
\hline 3 & Depok Rejo & 362.00 & 130.71 & 492.71 \\
\hline
\end{tabular}


152 Habib Ismail dan Nur Alfi Khotamin: Perkawinan dalam Masa ..

\begin{tabular}{|c|c|c|c|c|}
\hline 4 & Tempuran & 360.00 & 124.20 & 484.20 \\
\hline 5 & Simbarwaringin & 347.60 & 142.05 & 489.65 \\
\hline 6 & Trimurjo & 355.96 & 117.66 & 473.62 \\
\hline 7 & Notoharjo & 389.70 & 87.30 & 477.00 \\
\hline 8 & Untoro & 216.00 & 95.60 & 311.60 \\
\hline 9 & Purwodadi & 296.61 & 55.42 & 352.03 \\
\hline 10 & Purwoadi & 351.50 & 149.25 & 500.75 \\
\hline 11 & Pujodadi & 128.00 & 142.00 & 270.00 \\
\hline 12 & Pujo Kerto & 312.00 & 107.50 & 419.50 \\
\hline 13 & Pujo Basuki & 202.00 & 57.00 & 259.00 \\
\hline 14 & Pujo Asri & 260.00 & 58.50 & 328.50 \\
\hline \multicolumn{2}{|r|}{ Jumlah } & 4.323 .07 & 1.550 .46 & $\begin{array}{c}5.782 .5 \\
3\end{array}$ \\
\hline
\end{tabular}

Adapun rincian mengenai jumlah masing-masing pemeluk Agama serta persebarannya di kecamatan trimurjo dapat dilihat pada table berikut:

Tabel 2

Jumlah penduduk menurut Agama yang dianut di Kecamatan Trimurjo

\begin{tabular}{|c|c|c|c|c|c|c|c|}
\hline \multirow{2}{*}{ No } & \multirow[b]{2}{*}{$\begin{array}{c}\text { Desa/ } \\
\text { Kampung }\end{array}$} & \multicolumn{5}{|c|}{ Agama } & \multirow[b]{2}{*}{$\begin{array}{c}\text { Jumla } \\
\mathrm{h}\end{array}$} \\
\hline & & Islam & $\begin{array}{c}\text { Katoli } \\
\text { k }\end{array}$ & $\begin{array}{c}\text { Kriste } \\
\mathrm{n}\end{array}$ & $\begin{array}{c}\text { Hind } \\
\mathrm{u}\end{array}$ & $\begin{array}{c}\text { Budh } \\
\text { a }\end{array}$ & \\
\hline 1 & Adipuro & 5.797 & 10 & - & - & - & 5.807 \\
\hline 2 & $\begin{array}{l}\text { Liman } \\
\text { Benawi }\end{array}$ & 3.910 & - & 9 & - & - & 3.919 \\
\hline 3 & Depok Rejo & 3.581 & 4 & 1 & - & - & 3.586 \\
\hline 4 & Tempuran & 3.417 & 145 & 58 & 2 & 8 & 5.630 \\
\hline 5 & $\begin{array}{l}\text { Simbarwaring } \\
\text { in }\end{array}$ & 5.903 & 28 & - & 13 & 3 & 5.947 \\
\hline 6 & Trimurjo & 3.885 & 68 & 52 & 863 & - & 4.868 \\
\hline 7 & Notoharjo & 2.743 & 50 & - & - & - & 2.793 \\
\hline 8 & Untoro & 2.565 & 4 & - & - & - & 2.569 \\
\hline 9 & Purwodadi & 5.632 & 37 & 100 & 6 & 11 & 5.786 \\
\hline 10 & Purwoadi & 2.326 & 15 & 81 & - & - & 2.422 \\
\hline 11 & Pujodadi & 1.988 & 1 & 11 & - & - & 2.000 \\
\hline 12 & Pujo Kerto & 2.504 & 47 & 11 & - & - & 2.562 \\
\hline 13 & Pujo Basuki & 1.325 & 14 & - & - & - & 1.339 \\
\hline 14 & Pujo Asri & 1.234 & 4 & - & 223 & - & 1.470 \\
\hline & Jumlah & $\begin{array}{c}48.81 \\
9\end{array}$ & 427 & 323 & $\begin{array}{c}1.10 \\
7\end{array}$ & 22 & $\begin{array}{c}50.69 \\
8\end{array}$ \\
\hline
\end{tabular}


Data pendidikan di Kecamatan Timurjo menurut tingkatan dan jenis sekolah.

Tabel. 3

Banyaknya siswa menurut tingkatan sekolah dan jenis sekolah di Kecamatan Trimurjo Tahun 2014.

\begin{tabular}{|c|l|c|c|c|}
\hline No & Tinakatan Sekolah & Negeri & Swasta & Jumlah \\
\hline 1 & Taman Kanak-kanak & 118 & 662 & 780 \\
\hline 2 & Sekolah Dasar & 4.907 & - & 4.907 \\
\hline 3 & Madrasah Ibtidaiyah & - & 156 & 156 \\
\hline 4 & SLTP Umum & 1.616 & 529 & 2.145 \\
\hline 5 & Madrasah Tsanawiyah & - & 203 & 203 \\
\hline 6 & Madrasah Aliyah & - & - & - \\
\hline 7 & SMU & 555 & 313 & 868 \\
\hline 8 & STM & - & - & - \\
\hline 9 & SMEA & - & - & - \\
\hline \multicolumn{2}{r}{ Jumlah } & 7.196 & 1.863 & 9.059 \\
\hline
\end{tabular}

\section{Faktor dan Dampak Perkawinan dalam Masa 'Iddah di Kecamatan Trimurjo Lampung Tengah}

Fakta di kecamatan Trimurjo menunjukkan terdapat satu kasus pelanggaran terhadap UU perkawinan No. 1 Tahun 1974 mengenai metode penetapan masa iddah yang tertuang dalam pasal 39 ayat 1-3 UU No. 1 Tahun 1974. Kasus tersebut adalah sebagai berikut:

Di kelurahan Simbarwaringin Kecamatan Trimurjo, yaitu seorang istri yang bernama Ibu Aisyah yang berusia 42 tahun dengan status janda ditinggal mati suami. Ibu Aisyah menikah dengan seorang pria yang bernama Bapak Plontang yang berasal dari lingkungan V Simbarwaringin. Pernikahan tersebut dilaksanakan pada hari Jum'at yang bertepatan tanggal 20 Januari Tahun 2017 Pukul \pm 20.00 WIB. Dalam pernikahan tersebut Ibu Aisyah masih dalam masa iddah, dimana masa iddah tersebut adalah 4 bulan 10 hari sebagaimana firman Allah Swt: 


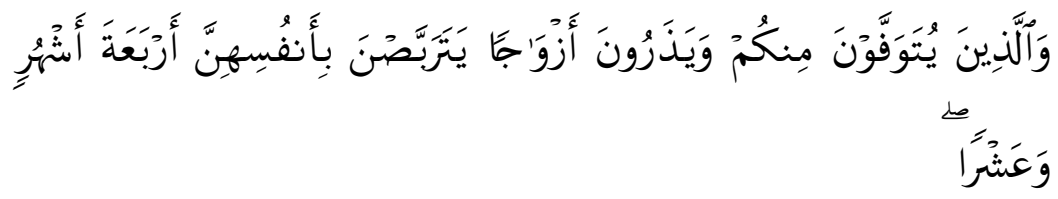

Artinya "Orang-orang yang meninggal dunia di antaramu dengan meninggalkan isteri-isteri (hendaklah para isteri itu) menangguhkan dirinya (ber'iddah) empat bulan sepuluh hari.(QS. Al-Baqarah: 234)

Ayat diatas senada dengan rujukan Kompilasi Hukum Islam (KHI) pasal 153 ayat 2 point (a) dalam menetapkan masa iddah mati dengan teks yang menyatakan "apabila perkawinan putus karena kematian, walaupun qobla al dukhul, waktu tunggu ditetapkan 130 (seratus tiga puluh) hari."

Dalam pernikahan tersebut Ibu Aisyah diwalikan oleh Pamannya. ${ }^{37}$ Secara pendidikan agama, bapak Komari dapat dikategorikan kurang dalam pemahaman pendidikan agama. Sedangkan dari segi ekonomi, berada pada garis perekonomian yang biasa-biasa saja.

Sedangkan selaku penghulu yang menikahkan Ibu Aisyah adalah Pak Joko Budianto, yang memiliki latar belakang pendidikan agama, yaitu sebagai alumni santri ponpes di Jawa Timur, sehingga secara keilmuan agama cukuplah mendapat pengakuan dari masyarakat sekitar simbarwaringin meskipun tidak memiliki kedudukan sebagai pejabat pemerintah (Tokoh Publik) maupun pejabat Agama (Tokoh Agama) di kelurahan Simbarwaringin. Maka jika dilihat dari aturan syariat masa idah, Pak Joko Budianto selaku penghulu yang menikahkan Ibu Aisyah sudah mengetahui dasar hukum mengenai pelaksanaan perkawinan yang dilakukan pada masa iddah adalah merupakan salah satu pelanggaran terhadap hukum teologis dan hukum normatif. ${ }^{38}$

Dari data-data temuan yang didapat dari lokasi penelitian yaitu dikelurahan Simbarwaringin kecamatan

\footnotetext{
${ }^{37}$ Wawancara dengan Bapak Komari paman Ibu Aisyah pada hari Minggu, tanggal 19 Maret 2017

38 Wawancara dengan Kepala KUA Kelurahan Simbarwaringin pada hari Rabu, tanggal 22 Maret 2017.
} 
trimurjo, penulis dapat menguraikan bahwasanya faktorfaktor yang menyebabkan ibu Aisyah melakukan pernikahan dalam masa iddah (iddah mati) adalah, yang pertama, faktor pendidikan atau pengetahuan. Faktor ketidaktahua ibu Aisyah akan adanya masa iddah dalam Islam. Hal ini menunjukkan bahwasanya ibu Aisyah kurang sekali pemahamannya dalam ilmu agama. Yang kedua, adalah faktor gangguan eksternal yang biasanya dalam masyarakat disebut sebagai gangguan sihir (pelet) yang dilakukan oleh pihak pria yaitu bapak Plontang untuk menghilangkan alam bawah sadar dari ibu Aisyah untuk mengikuti keinginannya yaitu menikah dengannya.

Ketiga, faktor biologis, dan keempat, adalah faktor ekonomi yang menjadikan ibu Aisyah melakukan pernikahan dalam masa iddah tersebut. Inilah permaslaahanpermasalahan yang menyebabkan ibu Aisyah melakukan pernikahan tersebut.

Secara keseluruhan, fenomena pernikahan dalam masa 'iddah seperti ini bertolak belakang dari teori maqasid asysyari'ah (tujuan hukum Islam), Allah Swt. yang mensyariatkan bahwa hukum-Nya bertujuan untuk memelihara terhadap keturunan atau hifzh al-nasl. Memelihara keturunan dalam tingkat dharuriyyat adalah seperti pensyariatan hukum perkawinan dan larangan berzina. Apabila ketentuan ini diabaikan maka eksistensi keturunan akan terancam. ${ }^{39}$ Sama dengan sifat nikah yang batal karena pernikahan terjadi saat perempuan masih menjalani masa 'iddah. Sehingga, tujuan Hukum Islam yang hendak dicapai akan rusak, karena cacatnya pemeliharaan terhadap keturunan.

Adapun seperti yang peneliti ungkapkan pada bab II tentang 'iddah yang bersifat ta'abuddi atau ibadah, memberikan dampak terhadap kewajiban dari 'iddah itu sendiri. Bahwa tidak ada istilah rukhsah atau keringanan dalam perhitungan 'iddah yang dijalankan seorang janda, baik cerai hidup maupun cerai mati. Jadi, hukum pernikahan janda dalam masa 'iddah seperti ini jelas keharamannya. Jika

${ }^{39}$ Mardani, Hukum Islam: Pengantar Hukum Islam di Indonesia, (Yogyakarta: Pustaka Pelajar, 2010), h. 23 
dukhul, maka hubungan suami istri di anggap zina, dan akibatnya berdampak pada status anak, waris dan sebagainya.

Satria Effendi M. Zein dalam bukunya yang berjudul Problematika Hukum Keluarga Islam Kontemporer: Analisis Yurisprudensi dengan Pendekatan Ushuliyah bahwa:

Nikah wanita yang sedang beriddah, nikah seperti ini jika sempat bersenggama setelah masing-masing mengetahui nikahnya batal, maka perbuatannya di anggap zina. Dan jika keduanya benar-benar belum mengetahui batalnya pernikahan itu atau tidak mengetahui adanya larangan menikahi wanita yang sedang beriddah karena baru masuk Islam misalnya, maka perbuatannya tidak di anggap zina, tetapi senggama subhat. ${ }^{40}$

Sebelumnya telah dijelaskan jika pernikahan yang batal tersebut pasangan suami istri itu melakukan senggama sampai memiliki anak, dan sepanjang itu pula tidak pernah dibatalkan nikahnya, maka status anak itu tidak jelas. Ada perbedaan antara orang yang tahu hukum dan orang yang tidak tahu hukum. Kalau seseorang melanggar hukum karena tidak tahu maka tidak ada hukum yang menimpa sebagai akibatnya. Berbeda dengan orang yang tahu, maka jelas hukum selalu mendampinginya. Hal ini sejalan dengan pandangan Wahbah Zuhaili bahwa, pada dasarnya suatu akad seperti akad nikah bila ternyata batal, maka tidak mempunyai hukum. Dan apabila terjadi senggama, hubungan suami istri itu tidak dianggap zina asalkan benar-benar tidak tahu hukum tentang itu. Akibatnya pun tidak pula di dera 100 kali bagi seorang yang belum pernah kawin, tidak pula di rajam bagi yang sudah pernah menikah. Jadi akibat hukumnya sama dengan yang terjadi dalam pernikahan sah, bahkan mengenai nasab anak.

Dari penjelasan sebelumnya, dapat ditarik kesimpulan bahwa sifat pernikahan yang fasid disebabkan tidak sempurnyanya rukun dan syarat sah nikah seperti pernikahan yang dilangsungkan pada masa 'iddah yang belum habis,

40 Satria Effendi, Problematika Hukum Keluarga Islam Kontemporer: Analisis Yurisprudensi dengan Pendekatan Ushuliyah, (Jakarta: Kencana, 2004), h. 24. 
maka hukumnya haram. Adapun langkah hukum yang diambil untuk menuntaskan masalah ini adalah fasakh nikah. Kemudian ada sisa kewajiban 'iddah yang belum selesai untuk dilanjutkan oleh perempuan tadi, dengan memperhatikan kewajiban adabnya ketika 'iddah kembali berlangsung. Selanjutnya jika masa 'iddah-nya sudah berakhir, maka barulah perempuan tersebut bisa melangsungkan pernikahan dengan akad baru sesuai dengan tuntunan Agama dan Hukum Perkawinan di Indonesia. Inilah hukum-hukum Allah Swt. yang tidak boleh dilanggar. Karena ajaran-ajaran yang diberikan oleh Allah Swt. merupakan ajaran yang paling sempurna.Ini adalah bukti bahwa ada keindahan dalam setiap hukum Islam.

\section{E. Kesimpulan}

Dari penelitian dilapangan yang telah penulis lakukan, dapat disimpulkan bahwa:

1. Faktor-faktor pernikahan pada masa iddah, antara lain: pertama, faktor internal dan kedua, faktor eksternal. Faktor internal tersebut adalah lemahnya pendidikan (tertutama pendidikan agama), kondisi lemahnya ekonomi dan lemahnya kontrol terhadap kebutuhan biologis. Sedangkan faktor eksternal tersebut antara lain; lemahnya tingkat kontrol tokoh agama yang berwenang dan tokoh publik (pemerintahan) terhadap sikap religius keluarganya. Dan adanya pengaruh hal ghaib.

2. Dampak pernikahan pada masa iddah, antara lain; dampak terhadap individu dan dampak terhadap sosial. Dampak terhadap individu, yaitu turunnya kualitas kehidupan si individu dalam sikap keberagamaan (terjadi kumpul kebo dll), berkaitan dengan garis nasab dan waris. Sedangkan dampak sosialnya adalah pengucilan terhadap si pelaku pernikahan pada masa iddah karena tidak sesuai dengan kultur budaya yang berbasiskan Islam di Kecamatan Trimurjo. 


\section{Daftar Pustaka}

Abdul Azziz Muhammad Azzam dan Abdul Wahab Sayyed Hawwas, Fiqh Munakahat: Khitbah, Nikah, dan Talak, Alih bahasa Abdul Majid Khon, Jakarta: Amzah, 2009.

Ahsin W. Alhafidz, Kamus Fiqh, Jakarta: Amzah, 2013.

Ali Yusuf As-Subki, Fiqh Keluarga: Pedoman Berkeluarga dalam Islam, Jakarta: Amzah, 2010.

Amir Syarifuddin, Hukum Perkawinan Islam di Indonesia antara Fiqh Munakahat dan Undang-undang Perkawinan, Jakarta: Kencana Prenada Media Group, 2009.

An-Naisaburi dan Muslim bin al-Hajjaj al-Qusyairi, Ensiklopedia Hadits 3: Shahih Muslim 1, Alih bahasa Ferdinand Hasmand, dkk, Jakarta: Almahira, 2012.

Arso Sosroatmodjo, Wasit Aulawi, Hukum Perkawinan di Indonesia, Jakarta: Bulan Bintang, 1975.

Dewan Penterjemah, Al Qur"an dan Terjemahannya, Madinah: Mujammaee Al Malik Fahd Li Thiba at Al Mush-haf, 1971.

Ibnu Hajar Al Asqalani, Fathul Barri 26: Shahih Bukhari, Alih bahasa Amiruddin, Jakarta: Pustaka Azzam, 2008.

Ibnu Mas'ud dan Zainal Abidin S, Fiqih Madzhab Imam Syafi'I, (Bandung: Pustaka Setia, 2007).

Ibnu Rusyd, Bidayatul Mujtahid Analisis Fiqih Para Mujtahid, Alih Bahasa Imam Ghazali Said dan Achmad Zaidun, (Jakarta: Pustaka Amani, 2007).

Iddah Dalam Keadilan Gender, Jurnal Studi Gender \& Anak Vol.5 No.1 Jan-Jun 2010 pp.103-127.

Imam Ghazali Said dan Achmad Zaidun, Terjemah Bidayatul Mujtahid Analisis Fiqih Para Mujtahid, (Jakarta: Pustaka Amani, 2017).

Imam Jalaluddin Al-Mahalli dan Imam Jalaluddin AlSuyuthi, Tafsir Jalalain 1: Berikut Asbaabun Nuzuul 
Ayat, Alih bahasa Bahrun Abu Bakar, Bandung: Sinar Baru Algesindo, 1996.

Imam Syafi'i, Mukhtasar Kitab Al-Umm Fi Al-Fiqh, diterjemahkan Muh. Yasir Muthalib Cet 3, Jakarta: Pustaka Azzam, 2007.

Indar, Iddah Dalam Keadilan Gender, Jurnal Studi Gender \& Anak Vol.5 No.1 Jan-Jun 2010.

Kamal Muhtar, Asas Hukum Perkawinan, cet. II, Jakarta: Bulan Bintang, 1987.

Mardani, Hukum Islam: Pengantar Hukum Islam di Indonesia, (Yogyakarta: Pustaka Pelajar, 2010).

Muhammad Ali Ash-Shabuni, Terjemahan Tafsir Ayat Ahkam Ash-Shabuni, Alih bahasa Mu'ammal Hamidy dan Imron A. Manan, Surabaya: PT Bina Ilmu, 2008.

Salim Bahreisy dan Said Bahreisy (pengh. dan pent.), Terjemah Singkat Tafsir Ibnu Katsir Jilid 1, Surabaya: PT. Bina Ilmu, 2006.

Satria Effendi, Problematika Hukum Keluarga Islam Kontemporer: Analisis Yurisprudensi dengan Pendekatan Ushuliyah, (Jakarta: Kencana, 2004).

Sayyid Sabiq, Fiqih Sunnah 3, Alih bahasa M. Ali Nursyidi dan Hunainah M. Thahir Makmun, Jakarta: PT. Pena Pundi Aksara, 2009.

Siti Zulaikha, Iddah Dan Tantangan Modernitas, ISTINBATH Jurnal Hukum Vol. 7 Nomor 1 Mei 2010.

Soemiyati, Hukum Perkawinan dan Undang-undang Perkawinan, cet. I, Yogyakarta: Liberty, 1982.

St. Kuraedah, Hadis Tentang Iddah Wanita Hamil Yang Ditinggal Mati Oleh Suaminya, Jurnal Al-‘Adl, Vol. 6 No. 1 Januari 2013.

Sulaiman Rasyid, Fiqh Islam, Bandung: Sinar Baru Algensindo, 1994. 
160 Habib Ismail dan Nur Alfi Khotamin: Perkawinan dalam Masa ..

Syarifudin Anwar dan Misbah Musthafa, Terjemah Kifayatul Ahyar Kelengkapan Orang Saleh, (Surabaya: Bina Iman).

Umi Hasunah, Susanto, Iddah Perempuan Hamil karena Zina dalam Kompilasi Hukum Islam Pasal 53, Jurnal Hukum Keluarga Islam Volume 1, Nomor 1, April 2016.

Wawancara dengan Bapak Komari paman Ibu Aisyah pada hari Minggu, tanggal 19 Maret 2017.

Wawancara dengan Kepala KUA Kelurahan Simbarwaringin pada hari Rabu, tanggal 22 Maret 2017.

Zainuddin Ali, Hukum Perdata Islam di Indonesia, Jakarta: Sinar Grafika, 2009. 